\title{
Decreased pancreatic islet response to L-leucine in the spontaneously diabetic GK rat: enzymatic, metabolic and secretory data
}

\author{
M.-H. Giroix, C.Saulnier, B. Portha \\ Laboratory of Nutrition Physiopathology, University of Paris 7 (Denis Diderot), Paris, France
}

\section{Abstract}

Aims/hypothesis. Pancreatic islets from hereditarily non-insulin-dependent diabetic Goto-Kakizaki (GK) rats have a deficient insulin response not only to D-glucose but also to L-leucine. Our aim was to explain the cellular mechanism(s) underlying the betacell unresponsiveness to this amino acid.

Methods. Freshly collagenase isolated islets from GK rats and healthy Wistar control rats matched with them for sex and age were compared. Leucine uptake, metabolic fluxes and insulin secretory capacity were investigated on batch incubated-islets. Enzymatic activities were measured on sonicated islets.

Results. In GK rat islets, neither leucine transport nor leucine transaminase activity was disturbed. By contrast, ${ }^{14} \mathrm{CO}_{2}$ production from either $\mathrm{L}-\left[\mathrm{U}-{ }^{14} \mathrm{C}\right]$ leucine or L-[1- $\left.{ }^{14} \mathrm{C}\right]$ leucine was decreased. The $\mathrm{L}-\left[\mathrm{U}_{-}{ }^{14} \mathrm{C}\right] \mathrm{leu}-$ cine oxidation : $\mathrm{L}-\left[\mathrm{I}^{\mathrm{I}}{ }^{4} \mathrm{C}\right]$ leucine decarboxylation ratio was unaffected, indicating that the acetyl-CoA generated from leucine undergoes normal oxidation in the Krebs cycle. The leucine non-metabolizable analogue 2-amino-bicyclo[2,2,1]heptane-2-carboxylic acid induced insulin release and enhanced the secretory response to leucine as in controls, whereas leucine failed to amplify the response to the leucine analogue. Moreover, the potentiating action of L-glutamine on leucine-mediated insulin release was preserved. This coincided with normal glutamate dehydrogenase activity and $\mathrm{L}-\left[\mathrm{U}-{ }^{14} \mathrm{C}\right]$ glutamine oxidation. Finally, the secretory response to the leucine deamination product 2-ketoisocaproate was decreased, as was the 2-keto[1-14 C]isocaproate oxidation.

Conclusion/interpretation. In islet beta cells from GK rats, the defective secretory response to leucine cannot be ascribed to a deteriorated leucine-stimulated glutamate metabolism but rather to an impaired leucine catabolism. A reduced generation of acetylCoA from 2-ketoisocaproate, due to the defective oxidative decarboxylation of this keto-acid by the mitochondrial branched-chain 2-ketoacid dehydrogenase, is incriminated. [Diabetologia (1999) 42: 965977]

Keywords L-leucine, pancreatic islets, GK rat, noninsulin-dependent diabetes.
Received: 13 January 1999 and in final revised form: 1 April 1999

Corresponding author: Dr. M.-H. Giroix, Laboratoire de Physiopathologie de la Nutrition, ESA CNRS 7059, Université Paris 7 (Denis Diderot), tour 23/33, $1^{\text {er }}$ étage, 2 place Jussieu, F-75251 Paris cedex 05, France

Abbreviations: $\mathrm{BCH}, \quad 2-A$ mino-bicyclo[2,2,1]heptane-2-carboxylic acid; BCKDH, branched-chain 2-ketoacid dehydrogenase; DAB, 3,3'-diaminobenzidine-tetrahydrochloride; FAD, flavine adenine dinucleotide; GLUT 2, glucose transporter isoform 2; GK rat, Goto-Kakizaki rat; KIC, 2-ketoisocaproate; PDH, pyruvate dehydrogenase.
One of the major characteristic features of Type II (non-insulin-dependent) diabetes mellitus is the decreased ability of pancreatic beta cells to release insulin in response to stimulation by the carbohydrate D-glucose, the most potent physiological insulin secretagogue. Such a disturbance in islet function occurs in the GK rat [1-7], a genetic non-overweight model of Type II diabetes which was obtained through repetitive selective inbreeding of normal Wistar rats with a plasma glucose concentration in the upper normal range, as shown by an oral glucose tolerance test $[8,9]$. Even though the reasons for the 


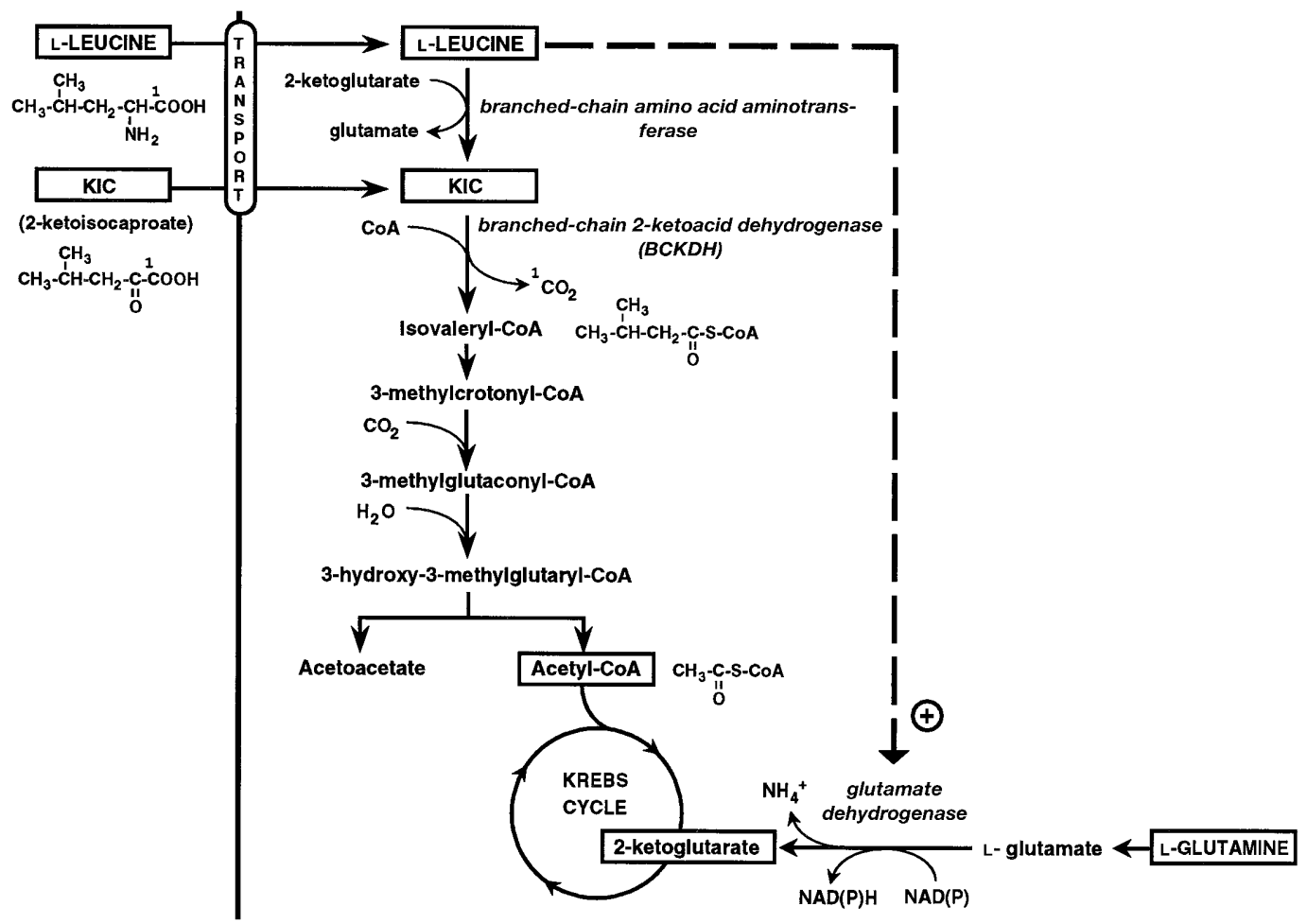

Fig. 1. Simplified representation for the mechanisms of action of L-leucine in pancreatic islet beta cells. The process by which L-leucine stimulate insulin release is thought to rely on an increase in catabolic fluxes in the islet beta cells via two main routes, first, the own catabolism of L-leucine [17-20] and second, the leucine-stimulated glutamate catabolism [20-25]. L-leucine entered the islet cells using mainly a $\mathrm{Na}^{+}$-independent transport known as system L [26, 27]. In the first pathway, the amino-acid is metabolized in the beta-cell mitochondria by first undergoing deamination to yield 2-ketoisocaproate (KIC). This reaction (transamination), catalysed by a branched-chain amino-acid aminotransferase (mentioned in the text as leucine transaminase), is coupled with the conversion of a suitable 2-keto-acid to the corresponding amino-acid (e.g. the conversion of 2-ketoglutarate to L-glutamate). Then, an oxidative decarboxylation, catalysed by the branched-chain 2-ketoacid dehydrogenase (BCKDH) multienzyme complex, convertes the deamination product of leucine, KIC, into isovaleryl-coenzyme A. This latter product is further degraded and, after several conversions, forms free acetoacetate and acetylcoenzyme A which enter the citric acid cycle (Krebs cycle) for complete oxidation to $\mathrm{CO}_{2}$ and $\mathrm{H}_{2} \mathrm{O}$. In the second pathway, L-leucine acts as an allosteric activator of glutamate dehydrogenase in beta cells. By doing so, it increases the oxidative deamination of endogenous glutamate and, hence, the formation of 2-ketoglutarate which is further oxidized in the Krebs cycle. The accelerated flux through each of these two pathways leads to an increase in necessary metabolic intermediates that govern the release of insulin, the biophysical events linking the metabolism of the exogenous or endogenous amino-acid and the exocytosis of insulin granules being similar to those involved in the response to D-glucose [28-30] deterioration in responsiveness of beta cells to the hexose in the GK rodent model remain to a large extent unclear, several site-specific lesions within islet beta cells have been described as possible contributing or causal factors for this secretory dysfunction. Among them are the underexpression of the glucose transporter 2 (GLUT-2) [4], the wasting of ATP in a futile cycle between D-glucose and D-glucose 6-phosphate [5] and the inadequate aerobic (oxidative) glycolysis $[3,10]$. The latter perturbation results from either a decrease in the mitochondrial activity of flavine adenine dinucleotide (FAD)-dependent glycerophosphate dehydrogenase and the ensuing reduced metabolic flux through the glycerol phosphate shuttle $[6,11-15]$ or a decrease in the pyruvate dehydrogenase activity [16].

We previously documented further evidence that islets obtained from these spontaneously diabetic rats exhibit a reduced insulin output in response not only to D-glucose but also to the essential amino acid L-leucine [3]. This is normally a potent amino acid in promoting insulin both in vivo and in vitro and can stimulate the beta cell in the absence of extracellular glucose. This study is an attempt to explain the so far unexplored biochemical mechanisms underlying the defective beta-cell responsiveness to the amino acid in the GK rat islets.

L-leucine is known to stimulate insulin release in normal beta cells by two intramitochondrial mechanisms: firstly the own catabolism of L-leucine [17-20] and secondly the allosteric activation of glutamate dehydrogenase resulting in an acceleration of the catabolism of L-glutamate synthesized from L-glutamine 
[20-25]. Both mechanisms lead to an increase of the metabolic flux rate through the Krebs cycle [20] (Fig.1). These two metabolic pathways have been investigated in pancreatic islets freshly isolated from either GK rats or, as controls, Wistar rats.

\section{Materials and methods}

Animals. All the animals were adult male rats. Diabetic GK rats were obtained from our local colony initiated in Paris in 1988 [2] with progenitors issued from the 35 th generation in the original colony established by Goto and Kakizaki $[8,9]$. Wistar rats raised in parallel were used as control animals. The rats were weaned 28 days after birth and then were allowed free access to tap water and a standard pelleted chow (diet 113, Rational Food Factory (Usine d'Alimentation Rationnelle), Villemoisson-sur-Orge, France) up to the time of the experiments. Experiments were carried out in accordance with the ethical rules of animal experimentation recommended by french legislation and the 'principles of laboratory animal care' (NIH publication no. 85-23, revised 1995).

Blood collection and islet preparation. At the time of the experiments, the rats were weighed and killed by exsanguination, blood samples being collected in heparinized tubes. After centrifugation for $10 \mathrm{~min}$ at $1000 \times g$ and $4{ }^{\circ} \mathrm{C}$, the plasma was removed and stored at $-20^{\circ} \mathrm{C}$ for further glucose and insulin determinations.

In each experiment, islets were isolated from the pancreas of 2-6 rats for each type of animal by a collagenase digestion technique [27] and subsequently separated from the remaining non-endocrine tissue by hand picking under a stereomicroscope. Collagenase produced from Clostridium histolyticum (EC 3.4.24.3, type P) was purchased from Boehringer Mannheim (Mannheim, Germany). Hanks' balanced salt solution satured with a mixture of $95 \% \mathrm{O}_{2}$ and $5 \% \mathrm{CO}_{2}$ was used during the isolation procedure. The freshly isolated islets were immediately used for experiments.

Leucine uptake. Uptake of L-leucine by islets was studied using an oil filtration technique as described previously [32]. Islets were preincubated for $30 \mathrm{~min}$ in a modified [33] KRB buffer $\left(115 \mathrm{mmol} / \mathrm{l} \mathrm{NaCl}, 5 \mathrm{mmol} / \mathrm{l} \mathrm{KCl}, 1 \mathrm{mmol} / 1 \mathrm{CaCl}_{2}, 1 \mathrm{mmol} / 1\right.$ $\mathrm{MgCl}_{2}$, and $24 \mathrm{mmol} / \mathrm{l} \mathrm{NaHCO}$ ) containing $5 \mathrm{~g} / \mathrm{l} \mathrm{BSA} \mathrm{(frac-}$ tion V; Sigma Chemical Co., St. Louis, Mo., USA) and equilibrated against a mixture of $95 \% \mathrm{O}_{2}$ and $5 \% \mathrm{CO}_{2}$. Thereafter, islets (in groups of $12 \mathrm{each}$ ) were incubated for $10 \mathrm{~min}$ at different temperatures $\left(5,25\right.$ or $\left.37^{\circ} \mathrm{C}\right)$ in $100 \mu \mathrm{l}$ of the same buffer also containing $\mathrm{L}-\left[1-{ }^{14} \mathrm{C}\right]$ leucine $(10 \mathrm{mmol} / \mathrm{l}, \quad 377 \mathrm{kBq} / \mathrm{ml}$; Amersham International, Amersham, UK), together with ${ }^{3} \mathrm{H}_{2} \mathrm{O}$ (1.85 MBq/ml; New England Nuclear, Boston, Mass., USA) as a measure of intracellular plus extracellular volume. In a limited number of experiments, $\mathrm{L}-\left[1-{ }^{14} \mathrm{C}\right]$ leucine was replaced by L-[1- $\left.{ }^{14} \mathrm{C}\right]$ glucose $(2 \mathrm{mmol} / \mathrm{l}, 277 \mathrm{KBq} / \mathrm{ml}$; New England Nuclear) used as an extracellular marker, to assess islet cell volume. A layer of $150 \mu \mathrm{l}$ silicone oil (Versilube F-50; General Electric Co., Waterford, N. Y., USA) was placed on the incubation medium. After incubation, the tubes were centrifuged (Beckman Microfuge E; Beckman Instruments, Palo Alto, Calif., USA) and the tip of the tube containing the pellet of islets was removed with a scalpel and examined for its radioactive content. After correction for the blank values found in the absence of islets $(7.06 \pm 0.50 \mathrm{nl} / \mathrm{sample} ; n=22)$, the apparent distribution spaces were expressed as $\mathrm{nl} /$ islet.
Enzymatic activities. Islets were sonicated in a HEPES-NaOH buffer (10 mmol/l, $\mathrm{pH} 7.0)$, containing $250 \mathrm{mmol} / \mathrm{l}$ sucrose, $2 \mathrm{mmol} / \mathrm{l}$ cysteine, $2 \mathrm{mmol} / \mathrm{l}$ EDTA and $0.2 \mathrm{~g} / \mathrm{l} \mathrm{BSA}$, to yield one islet per $\mu$.

Leucine transaminase activity was measured by two radioisotopic procedures based on the conversion of $\mathrm{L}-\left[1-{ }^{14} \mathrm{C}\right] \mathrm{leu}-$ cine to $2-\left[1-{ }^{14} \mathrm{C}\right]$ ketoisocaproate and $2-\left[1-{ }^{14} \mathrm{C}\right]$ ketoglutarate to $\mathrm{L}-\left[1-{ }^{14} \mathrm{C}\right]$ glutamate, respectively [34]. Briefly, an aliquot $(20 \mu \mathrm{l})$ of the islet homogenate was mixed with an equal volume of a reaction mixture consisting of a TRIS-HCl buffer (100 mmol/l, pH 8.4) containing $2 \mathrm{mmol} / \mathrm{l}$ dithiotreitol, $1 \mathrm{mmol} / \mathrm{l}$ pyridoxal phosphate and either L-leucine $(20 \mathrm{mmol} / \mathrm{l})$ together with a tracer amount of $\mathrm{L}-\left[1-{ }^{14} \mathrm{C}\right]$ leucine $(370 \mathrm{KBq} /$ $\mathrm{ml}$; Amersham International) and with or without 2-ketoglutarate $(2 \mathrm{mmol} / \mathrm{l})$, or 2-ketoglutarate $(2 \mathrm{mmol} / \mathrm{l})$ together with a tracer amount of $2-\left[1-{ }^{14} \mathrm{C}\right]$ ketoglutarate $(185 \mathrm{KBq} / \mathrm{ml}$; New England Nuclear) and with or without L-leucine $(20 \mathrm{mmol} / \mathrm{l})$. After $30 \mathrm{~min}$ of incubation at $37^{\circ} \mathrm{C}$, the reaction was stopped by diluting the reaction mixture with $1 \mathrm{ml}$ cold water $\left(0-4^{\circ} \mathrm{C}\right)$. Then, the ${ }^{14} \mathrm{C}$-labelled ketoisocaproate or glutamate formed during incubation was separated from its corresponding precursor $\left({ }^{14} \mathrm{C}\right.$-labelled leucine or ketoglutarate) by ion-exchange chromatography on a Dowex $50\left(\mathrm{H}^{+}\right.$form) resin (Fluka Chemicals, Buchs, Switzerland) [35]. Results were expressed as the amount of either $\mathrm{L}-\left[1-{ }^{14} \mathrm{C}\right]$ leucine converted to ${ }^{14} \mathrm{C}$-labelled ketoacid or $2-\left[1-{ }^{14} \mathrm{C}\right]$ ketoglutarate converted to ${ }^{14} \mathrm{C}$-labelled aminoacid, per ng islet DNA and per min. When required, the readings were corrected for the value found in the presence of islet homogenate and the absence of substrate (2-ketoglutarate or L-leucine). In the first procedure based on the conversion of $\mathrm{L}-\left[1-{ }^{14} \mathrm{C}\right]$ leucine to $2-\left[1-{ }^{14} \mathrm{C}\right]$ ketoisocaproate, the above-mentioned value, obtained after correction for the blank value found in the absence of both substrate and homogenate, was negligible. In the second procedure based on the conversion of $2-\left[1-{ }^{14} \mathrm{C}\right]$ ketoglutarate to $\mathrm{L}-\left[1-{ }^{14} \mathrm{C}\right]$ glutamate, such a value averaged in control and GK groups respectively $10.4 \pm 1.5$ and $8.1 \pm 2.4 \%$ ( $n=3$ in both cases $)$ of the value obtained in the presence of both homogenate and substrate. This value reflects the transamination between the 2-[1$\left.{ }^{14} \mathrm{C}\right]$ ketoglutarate and the pool of endogenous aminoacids, as catalysed by tissue transaminases [35].

For measuring glutamate dehydrogenase activity, an aliquot $(20 \mu \mathrm{l})$ of a $1: 2$ dilution of the islet homogenate was mixed with the same volume of a TRIS-HCl buffer (100 mmol/l, pH 8.0) containing $50 \mathrm{mmol} / \mathrm{l}$ ammonium acetate, $2 \mathrm{mmol} / \mathrm{l} \mathrm{ADP}, 0.6 \mathrm{mmol} / 1 \mathrm{NADH}$, and $1.4 \mathrm{mmol} / 12$-ketoglutarate together with a tracer amount $(148 \mathrm{KBq} / \mathrm{ml})$ of 2-[1$\left.{ }^{14} \mathrm{C}\right]$ ketoglutarate (Amersham International). After $30 \mathrm{~min}$ of incubation at $37^{\circ} \mathrm{C}$, the reaction was stopped by the addition of $1 \mathrm{ml}$ cold water followed by the immediate separation of ${ }^{14}$ C-labelled glutamate [35]. Readings were corrected for the value found in the presence of islet homogenate and the absence of NADH. This value obtained after correction for the blank determination measured in the absence of both homogenate and NADH averaged, in the control and GK groups, respectively $1.7 \pm 0.3$ and $1.3 \pm 0.1 \%(n=3$ in both cases $)$ of the value measured in the presence of both homogenate and $\mathrm{NADH}$.

Islet glucose, pyruvate, leucine, ketoisocaproate and glutamine metabolism. Islet oxidation of exogenous nutrients was measured as described previously [36]. Radioactive precursors were obtained from the following sources: D- $\left[6-{ }^{14} \mathrm{C}\right]$ glucose, $\left[1-{ }^{14} \mathrm{C}\right]$ pyruvate, L-[U-14 C]leucine, L- $\left[1-{ }^{14} \mathrm{C}\right]$ leucine, 2-keto[1$\left.{ }^{14} \mathrm{C}\right]$ isocaproic acid, L-[U- $\left.{ }^{14} \mathrm{C}\right]$ glutamine from Amersham International and $\left[2-{ }^{14} \mathrm{C}\right]$ pyruvate from New England Nuclear. They were used at a final concentration of $370-481 \mathrm{KBq} / \mathrm{ml}$. 
Briefly, groups of 15 islets each from either control or GK rats were incubated for $120 \mathrm{~min}$ at $37^{\circ} \mathrm{C}$ in $40 \mu \mathrm{KRB}$ [33] containing $5 \mathrm{~g} / 1 \mathrm{BSA}$, the labelled substrate and non-radioactive glucose, pyruvate, leucine, ketoisocaproate or glutamine at the final concentration given in the text and figures. The incubation was stopped by adding $20 \mu \mathrm{l}$ of a citrate- $\mathrm{NaOH}$ buffer (400 mmol/l, pH 4.9) containing $5 \mathrm{mmol} / \mathrm{l} \mathrm{KCN}, 10 \mu \mathrm{mol} / \mathrm{l} \mathrm{ro}-$ tenone and $10 \mu \mathrm{mol} / \mathrm{l}$ antimycin $\mathrm{A}$. The ${ }^{14} \mathrm{CO}_{2}$ formed by the islets was determined by liquid scintillation counting after the ${ }^{14} \mathrm{CO}_{2}$ was trapped in $250 \mu \mathrm{l}$ hyamine hydroxide (Packard, Downers Grove, Ill., USA) over a 60-min incubation period at $20^{\circ} \mathrm{C}$. Blank incubations without islets were treated in the same way as those with islets. The blank values were substracted from the experimental values. Results were expressed by reference to the specific radioactivity of the incubation medium.

In some experiments, the acidified incubation media containing the islets were stored at $-20^{\circ} \mathrm{C}$ and later used for measurement of their content in ${ }^{14} \mathrm{C}$-labelled acidic metabolites or amino acids. For these measurements, the islets and incubation medium was mixed with $200 \mu \mathrm{l}$ of water and then sonicated. The ${ }^{14} \mathrm{C}$-labelled acidic metabolites (e.g. 2-keto isocaproate generated from L- $\left[1-{ }^{14} \mathrm{C}\right]$ leucine) and amino acids (e.g. alanine generated from radiolabelled pyruvate) were separated from their precursors by a chromatography method by passing the homogenate through an ion-exchange resin (Dowex 50, $\mathrm{H}^{+}$ form, column), as described previously [35]. The ${ }^{14} \mathrm{C}$-labelled acidic metabolites were collected from the column by washing with $3.5 \mathrm{ml}$ of water. The radioactive amino acids was eluted with $2 \mathrm{ml}$ of ammonium acetate $(1.0 \mathrm{~mol} / \mathrm{l})$ after extensive water washing of the column. Radioactivity was determined by liquid scintillation counting.

Insulin secretion. Insulin released from freshly isolated islets was measured in a static incubation system as described elsewhere [3]. Briefly, batches of seven islets each were incubated in a shaking water bath for $90 \mathrm{~min}$ at $37^{\circ} \mathrm{C}$ in $1 \mathrm{ml}$ of $\mathrm{KRB}$ buffer [33] containing $5 \mathrm{~g} / \mathrm{l} \mathrm{BSA}$ and equilibrated against a gas phase of $95 \% \mathrm{O}_{2}$ and $5 \% \mathrm{CO}_{2}$. Test agents were added as indicated in the Results section. At the end of the incubation period, samples of the incubation medium were removed and frozen until insulin assay for quantification of the released insulin.

Immunocytochemistry and morphometric quantification of insular cells. In three separate experiments two groups of 20 islets each isolated from control rats and GK rats, respectively, were fixed for $1 \mathrm{~h}$ in Bouin's solution. After three rinses in PBS, the islets were pre-embedded in 3\% agarose (ref. A6013 Sigma) at $60^{\circ} \mathrm{C}$ and the agarose was immediately hardened in ice for $20 \mathrm{~min}$. The islet pellet thus obtained was maintained overnight in $70 \%$ ethanol. It was then dehydrated in graded solutions of ethanol, cleared in xylene, and embedded in paraplast. Serial sections $(6 \mu \mathrm{m}$ thick $)$ were mounted on glycerine-albumin-coated glass slides. Adjacent sections from 4-5 selected islets in each islet preparation were deparaffined, rehydrated and processed for immunocytochemical staining of beta or non-beta endocrine cells, using a technique adapted from the peroxidase indirect labelling method [37], as described previously [38]. For immunostaining of beta cells, anti-insulin serum purchased from ICN (ref. 65-104-1; ICN Pharmaceutical, Orsay, France) and generated in guinea-pig against porcin insulin was used. Labelling was done using a peroxidase-conjugated rabbit anti-guinea pig IgG (ref. P0141; Dako, Trappes, France) and the activity of the peroxidase complex was revealed with 3,3'-diaminobenzidine-tetrahydrochloride (DAB) (KIT SK-4100; Vector, Biosys, Com- piègne, France). For immunostaining of non-beta endocrine cells a mixture of anti-glucagon serum (ref. 64-706-1; ICN) plus anti-somatostatin serum (ref. 64-714-1; ICN) plus antipancreatic polypeptide serum (ref. 64-711-1; ICN), all generated in rabbit, and peroxidase-conjugated goat anti-rabbit IgG (ref. 074-1506; KPL, Dynex Technologie, Issy-les-Moulineaux, France) were used. The peroxidase activity was revealed with DAB. Quantificative evaluation was done using computer-assisted image analysis by means of an Olympus $\mathrm{BX} 2$ microscope connected via a colour video camera to a compact PC computer using Imagenia 2000 software (Biocom; Les Ulis, France). The area of cells positive for insulin (or glucagon plus somatostatin plus pancreatic polypeptide) as well as that of total islet cells was evaluated in each stained section. The density of beta cells or non-beta endocrine (alpha, delta and PP) cells was determined according to a stereological method by calculating the ratio between the area occupied by immunoreactive cells and that occupied by total islet cells.

Glucose, insulin and DNA measurements. Plasma glucose concentration was measured by the glucose oxidase method [39] on $10 \mu \mathrm{l}$ plasma using a glucose analyser (Beckman Instruments).

Samples for plasma insulin determination and assessement of islet insulin secretory capacity were obtained as described above. For determination of islet insulin content, groups of 25 islets each were disrupted by sonication in $0.5 \mathrm{ml}$ redistilled water. A $25 \mu \mathrm{l}$ aliquot of the aqueous homogenate was mixed with $1.0 \mathrm{ml}$ of $\mathrm{KRB}$ containing $5 \mathrm{~g} / \mathrm{l} \mathrm{BSA}$. Insulin was measured by RIA using porcine $\left[{ }^{125} \mathrm{I}\right]$ monoiodinated insulin (Sorin Biomedica, Antony, France) as tracer [40], guinea-pig antiporcine insulin serum as antibody (final dilution $1: 400000$ ) and purified rat insulin (Novo Nordisk, Copenhagen, Denmark) as standard. Charcoal was used to separate free from bound hormone. The method allows the determination of $0.26 \mathrm{ng} / \mathrm{ml}$, with a coefficient of variation within and between assays of $10 \%$.

Islet DNA content was measured from either groups of 20 islets each kept dried at $-20^{\circ} \mathrm{C}$ or $5 \mu$ of the islet homogenates used for enzymatic determinations. DNA was assayed by a fluorometric method [41] adapted for islet tissue [42] using bisbenzimidazol (compound Hoechst 33258, Aldrich Chimica, Milano, Italy) as fluorochrome and calf thymus DNA (Sigma) as standard).

Presentation of results and statistical analysis. All results are expressed as the mean value $( \pm$ SEM) together with the number of individual determinations $(n)$, each collected in a distinct rat or group of islets. In all cases, the indicated number of batches of islets was obtained in at least three separate experiments. Statistical significance of differences between mean values was assessed by Student's $t$ test for unpaired data, the differences being considered significant at $p$ less than 0.05 .

\section{Results}

Characteristics of the animals. Table 1 (upper part) shows the basic characteristics of the diabetic GK and healthy (control) Wistar rats used in this study. Although of the same age, the GK rats had a lower body weight $(p<0.001)$ than control animals. In the fed state, GK rats had an abnormally high plasma glucose concentration $(p<0.001)$, despite slightly 
Table 1. Characteristics of control Wistar and diabetic GK rats used

\begin{tabular}{|c|c|c|}
\hline Rats & Control Wistar & Diabetic GK \\
\hline Age (weeks) & $17 \pm 2(89)$ & $18 \pm 1(104)$ \\
\hline Body weight $(\mathrm{g})$ & $415 \pm 5(76)$ & $297 \pm 4(88)^{\mathrm{a}}$ \\
\hline Non-fasting plasma insulin (ng/ml) & $5.7 \pm 0.3(52)$ & $6.8 \pm 0.3(69)^{\mathrm{b}}$ \\
\hline Plasma insulin/glucose ratio $(\mathrm{mg} / \mathrm{mol})$ & $0.83 \pm 0.04(52)$ & $0.76 \pm 0.04(69)$ \\
\hline Islet DNA content (ng/islet) & $21 \pm 1(30)$ & $16 \pm 1(29)^{\mathrm{c}}$ \\
\hline Beta cells per islet $(\%)$ & $79 \pm 1(3)$ & $62 \pm 2(3)^{\mathrm{a}}$ \\
\hline Non-beta endocrine (alpha, delta and PP) cells per islet (\%) & $12 \pm 2(3)$ & $13 \pm 1(3)$ \\
\hline Total endocrine (beta, alpha, delta and PP) cells per islet (\%) & $91 \pm 1(3)$ & $75 \pm 1(3)^{\mathrm{a}}$ \\
\hline Beta cells/total endocrine cells per islet $(\%)$ & $87 \pm 2(3)$ & $83 \pm 2(3)$ \\
\hline
\end{tabular}

Data are means \pm SEM. The number of distinct animals or islet preparations is shown in parentheses. In each experiment, the DNA and insulin content values were obtained from

Table 2. Distribution spaces of ${ }^{3} \mathrm{H}_{2} \mathrm{O}(55.5 \mathrm{~mol} / \mathrm{l})$, L- $\left[1-{ }^{14} \mathrm{C}\right] \mathrm{glu}-$ cose $(2.0 \mathrm{mmol} / \mathrm{l})$, and $\mathrm{L}-\left[1-{ }^{14} \mathrm{C}\right]$ leucine $(10.0 \mathrm{mmol} / \mathrm{l})$ in islets from control Wistar and diabetic GK rats, incubated for $10 \mathrm{~min}$ at 5,25 or $37^{\circ} \mathrm{C}$

\begin{tabular}{lll}
\hline Rats & Control Wistar & Diabetic GK \\
\hline $\begin{array}{l}\text { Total }{ }^{3} \mathrm{H}_{2} \mathrm{O} \text { space }(\text { nl/islet }) \\
\text { L- }\left[1-{ }^{14} \mathrm{C}\right] \text { glucose space } \\
(\text { nl/islet) }\end{array}$ & $4.32 \pm 0.20(106)$ & $3.75 \pm 0.26(100)$ \\
$\begin{array}{l}\mathrm{L}-\left[1-{ }^{14} \mathrm{C}\right] \text { glucose space/total } \\
{ }^{3} \mathrm{H}_{2} \mathrm{O} \text { space }(\%)\end{array}$ & $33 \pm 4(21)$ & $32 \pm 4(21)$ \\
$\mathrm{L}-\left[1-{ }^{14} \mathrm{C}\right]$ leucine space/total & & \\
${ }^{3} \mathrm{H}_{2} \mathrm{O}$ space $(\%)$ & $37 \pm 3(43)$ & $36 \pm 3(40)$ \\
$\quad 5^{\circ} \mathrm{C}$ & $60 \pm 4(23)$ & $66 \pm 5(18)$ \\
$25^{\circ} \mathrm{C}$ & $76 \pm 7(21)$ & $81 \pm 7(21)$ \\
$\quad 37^{\circ} \mathrm{C}$ &
\end{tabular}

Data are means \pm SEM for the number of individual observations shown in parentheses and obtained from 3 or more separate experiments

raised insulinaemia $(p<0.02)$. The paired ratio between plasma insulin and glucose concentrations was not significantly decreased, however, in GK rats compared with control rats.

Characteristics of the islets. The mean DNA content of islets removed from diabetic GK rats was $79 \%$ $(p<0.005)$ of that of controls but the mean insulin content represented no more than $47 \%$ of that in control islets when expressed on a per islet basis (Table 1, lower part). Thus, when taking into account the lower DNA content of GK rat islets, the insulin content per ng of islet-DNA remained lower $(p<0.01)$ in diabetic rat islets than in controls. Moreover, our histological data (Table 1, lower part) show that in islets from GK rats the beta-cell : islet surface ratio is decreased compared with control islets
$2-5$ groups of 20 islets each and the percentages of beta and non-beta cells were estimated in 4-5 islets.

${ }^{\mathrm{a}} p<0.001,{ }^{\mathrm{b}} p<0.02,{ }^{\mathrm{c}} p<0.005,{ }^{\mathrm{d}} p<0.01$, compared with related value in control group

$(p<0.001)$ to an extent similar $(21 \%)$ to the islet DNA content. Our data also indicate that there is no change in the relative contribution of beta cells to total endocrine cells in GK islets. Our results were therefore, whenever possible, expressed on the basis of paired islet DNA content to correct for the differences in islet size and beta-cell population of the diabetic and control specimens.

L-leucine uptake. When islets, whether from control or GK rats, were incubated for $10 \mathrm{~min}$ in the presence of ${ }^{3} \mathrm{H}_{2} \mathrm{O}$ and either ${ }_{\mathrm{L}-\left[1-{ }^{14} \mathrm{C}\right] \text { glucose }}$ $(2.0 \mathrm{mmol} / \mathrm{l})$ or $\mathrm{L}-\left[1-{ }^{14} \mathrm{C}\right]$ leucine $(10.0 \mathrm{mmol} / \mathrm{l})$, a change in temperature from 5 to 25 or $37^{\circ} \mathrm{C}$ failed to affect the ${ }^{3} \mathrm{H}_{2} \mathrm{O}$ space of which $32 \pm 3 \%(n=42)$ represents the extracellular space, as judged from the distribution space of $\mathrm{L}-\left[1-{ }^{14} \mathrm{C}\right]$ glucose. Pooling all available data, such a space value was found to be similar in control and GK rat islets, averaging $4.3 \pm 0.2$ and $3.7 \pm 0.3 \mathrm{nl} /$ islet $(n=100-106)$, respectively (Table 2). The islet intracellular volume, taken as the paired difference between the distribution spaces of ${ }^{3} \mathrm{H}_{2} \mathrm{O}$ and $\mathrm{L}-\left[1-{ }^{14} \mathrm{C}\right]$ glucose, tended to be lower in diabetic rats than control animals, averaging $2.4 \pm 0.2$ and $3.1 \pm 0.3 \mathrm{nl} /$ islet $(n=21$ in both), respectively. Such a difference failed, however, to achieve statistical significance (Fig. 2). Over $10 \mathrm{~min}$ of incubation at a low temperature $\left(5^{\circ} \mathrm{C}\right)$, the space of distribution of $\mathrm{L}-\left[1-{ }^{14} \mathrm{C}\right]$ leucine used at a concentration of $10.0 \mathrm{mmol} / \mathrm{l}$ was not significantly higher than the $\mathrm{L}-\left[1-{ }^{14} \mathrm{C}\right]$ glucose space, whether in control or diabetic rat islets (Table 2). Similar results were obtained by increasing the length of incubation from 5 to $30 \mathrm{~min}$ (data not shown). The distribution space of the amino acid augmented, however, as a function of the temperature. Thus, when results collected after $10 \mathrm{~min}$ of incubation at $5^{\circ} \mathrm{C}$ were com- 
Table 3. Enzymatic activities in islet homogenates from control Wistar and diabetic GK rats

\begin{tabular}{|c|c|c|}
\hline Rats & Control Wistar & Diabetic GK \\
\hline $\begin{array}{l}\text { Leucine-glutamate transaminase }\left(\mathrm{pmol} \cdot \mathrm{min}^{-1} \cdot \mathrm{ng} \text { islet } \mathrm{DNA}^{-1}\right) \\
\text { generation of }{ }^{14} \mathrm{C} \text {-labelled acidic metabolites from } \mathrm{L}-\left[1-{ }^{14} \mathrm{C}\right] \text { leucine } \\
\text { generation of }{ }^{14} \mathrm{C} \text {-labelled amino acids from } 2-\left[1-{ }^{14} \mathrm{C}\right] \text { ketoglutaric acid }\end{array}$ & $\begin{array}{l}0.35 \pm 0.03 \\
0.32 \pm 0.02\end{array}$ & $\begin{array}{l}0.43 \pm 0.12(3) \\
0.39 \pm 0.11\end{array}$ \\
\hline
\end{tabular}

Mean values $( \pm$ SEM) are derived from triplicate measurements in three separate experiments.

a The rate of transamination was recorded in the presence of $10.0 \mathrm{mmol} / \mathrm{l} \mathrm{L-}\left[1-{ }^{14} \mathrm{C}\right]$ leucine and $1.0 \mathrm{mmol} / \mathrm{l}$ unlabelled 2-ketoglutarate.

${ }^{\mathrm{b}}$ The rate of transamination was recorded in the presence of $1.0 \mathrm{mmol} / \mathrm{l} 2-\left[1-{ }^{14} \mathrm{C}\right] \mathrm{ketoglutarate}$ and $10.0 \mathrm{mmol} / \mathrm{l}$ unlabelled L-leucine.

When required the readings were corrected for the value found in the presence of islet homogenate and the absence of substrate (2-ketoglutarate of L-leucine for leucine-glutamate transaminase and NADH for glutamate dehydrogenase determinations). Such a value, corrected for the blank value found in the absence of both substrate and homogenate, averaged for the leucine-glutamate transaminase determination based on the conversion of $2\left[1-{ }^{14} \mathrm{C}\right]$ ketoglutarate to $\mathrm{L}-\left[1-{ }^{14} \mathrm{C}\right]$ glutamate $0.04 \pm 0.01$ and $0.03 \pm 0.01 \mathrm{pmol} \cdot \mathrm{min}^{-1} \cdot \mathrm{ng}$ islet $\mathrm{DNA}^{-1}$ in control and GK groups, respectively $(n=3$ in each case) and for glutamate dehydrogenase $0.03 \pm 0.01$ and $0.02 \pm$ $0.01 \mathrm{pmol} \cdot \mathrm{min}^{-1} \cdot \mathrm{ng}$ islet $\mathrm{DNA}^{-1}$ in control and GK groups, respectively ( $n=3$ in each case).

Enzymatic activities. The activity of leucine-glutamate transaminase in islet homogenates, as expressed relative to the paired DNA content of islets and whether measured with $\mathrm{L}-\left[1-{ }^{14} \mathrm{C}\right]$ leucine and 2-ketoglutarate or $2-\left[1-{ }^{14} \mathrm{C}\right]$ ketoglutarate and $\mathrm{L}$-leucine, failed to differ significantly in control and GK rats (Table 3).

The activity of glutamate dehydrogenase was also identical in islet homogenates from control and diabetic animals.

Glucose, pyruvate, leucine, ketoisocaproate and glutamine metabolism. In a first set of experiments the oxidation of glucose, leucine and glutamine was examined. In agreement with our previous observations $[3,10]$ the present data indicate that at a high concentration of D-glucose $(16.7 \mathrm{mmol} / \mathrm{l})$ the generation of ${ }^{14} \mathrm{CO}_{2}$ by islets exposed to D- $\left[6-{ }^{14} \mathrm{C}\right]$ glucose, which informs on the insular oxidation in the Krebs cycle of acetyl residues derived from exogenous D-glucose, is lower $(p<0.001)$ in GK than control Wistar rats $\left(13.9 \pm 1.6\right.$ vs $24.6 \pm 2.8 \mathrm{pmol} \cdot 120 \mathrm{~min}^{-1} \cdot$ islet $^{-1}, n=$ 44 and 28, respectively). In the islets from GK rats a decrease of about $30 \%$ ( $p<0.05$ or less) was recorded in ${ }^{14} \mathrm{CO}_{2}$ production whether in response to $10.0 \mathrm{mmol} / 1 \quad \mathrm{~L}-\left[1-{ }^{14} \mathrm{C}\right]$ leucine $\quad(30.9 \pm \quad 4.7 \mathrm{pmol}$. $120 \mathrm{~min}^{-1}$. islet $\left.{ }^{-1}, n=24\right)$ or L-[U- $\left.{ }^{14} \mathrm{C}\right]$ leucine (13.9 $\pm 1.9 \mathrm{pmol} \cdot 120 \mathrm{~min}^{-1}$. islet $\left.{ }^{-1}, n=24\right)$, compared with the values obtained in control islets $(43.6 \pm 3.8$ and $21.3 \pm 2.1 \mathrm{pmol} \cdot 120 \mathrm{~min}^{-1}$. islet ${ }^{-1}, n=28$, respectively). By contrast, the oxidative rate of L-[U${ }^{14} \mathrm{C}$ ] glutamine $(10.0 \mathrm{mmol} / \mathrm{l})$ was almost identical in both groups of islets.

The second set in this series of experiments aimed at comparing the two experimental groups in their oxidation of 2-ketoisocaproate and pyruvate, these two 2-ketoacids being produced from L-leucine and D-glucose, respectively. In GK rat islets incubated in the presence of $10.0 \mathrm{mmol} / \mathrm{l} 2$-keto[1-14 $\mathrm{C}]$ isocaproate, the output of ${ }^{14} \mathrm{CO}_{2}$ was $(p<0.05)$ lower $(55.8 \pm$ tal groups (control and diabetic) was observed, whatever the temperature of incubation. 


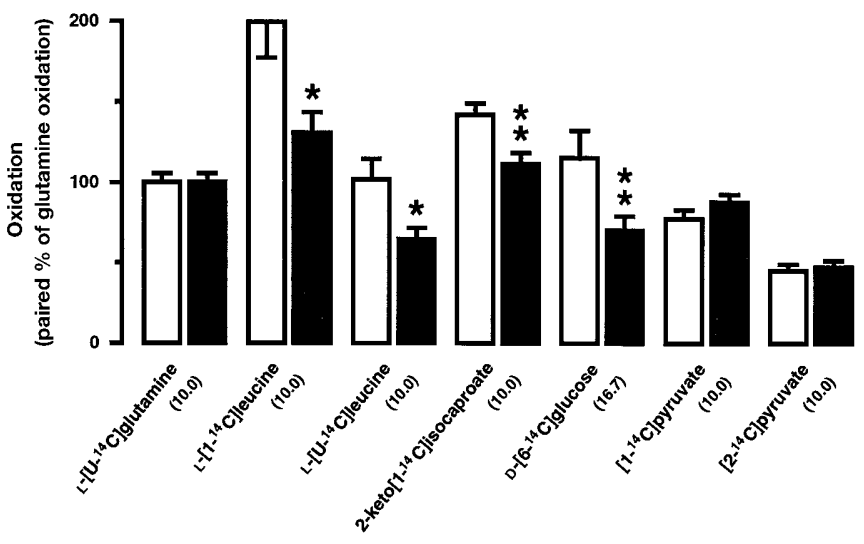

Nutrients (mmol/l)

Fig. 3. Nutrient oxidation in islets from control Wistar (open bars) and diabetic GK (solid bars) rats. All results are expressed relative to the mean reading of glutamine oxidation recorded within each experiment and in the same type of rats. Mean values \pm SEM refer to 18-44 individual observations, as derived from the primary data reported in Result section. Statistical significances of the observed differences between the two experimental groups are: *, $p<0.02$, **, $p<0.01$ (by Student's $t$ test for unpaired data)

$3.2 \mathrm{pmol} \cdot 120 \mathrm{~min}^{-1} \cdot$ islet $\left.^{-1}, n=30\right)$ than that recorded in control islets $\left(68.0 \pm 4.1 \mathrm{pmol} \cdot 120 \mathrm{~min}^{-1}\right.$. islet $^{-1}, n=39$ ). On the other hand, no difference between diabetic and control rats was observed in the insular ${ }^{14} \mathrm{CO}_{2}$ production from either $\left[1-{ }^{14} \mathrm{C}\right]$ pyruvate $\left(44.7 \pm 2.6\right.$ and $37.8 \pm 3.1 \mathrm{pmol} \cdot 120 \mathrm{~min}^{-1} \cdot$ islet $^{-1}$, $n=31-39$, in the GK and control group, respectively) or $\left[2-{ }^{14} \mathrm{C}\right]$ pyruvate $(24.3 \pm 1.9$ and $23.0 \pm 2.0 \mathrm{pmol}$. $120 \mathrm{~min}^{-1}$. islet ${ }^{-1}, n=31-39$, in the GK and control group, respectively).

Paired expression of the above-reported rough data are shown in Figures 3 and 4. The mean oxidative rate of $\mathrm{L}-\left[\mathrm{U}-{ }^{14} \mathrm{C}\right]$ glutamine was found similar in the two experimental groups. Pooling the data obtained in the two sets of experiments, such a rate averaged $41.0 \pm 3.0$ and $40.1 \pm 2.9 \mathrm{pmol} \cdot 120 \mathrm{~min}^{-1}$. islet $^{-1}$ in the islets from control and diabetic rats, respectively $(n=49-60)$. To take into account the differences between islets obtained from different preparations and groups of animals and in two distinct series of experiments L-glutamine oxidation, taken as a reflection of the amount of islet-cell material present in each sample, was therefore used as a reference value within each experiment for the oxidative data. When expressed relative to such a paired reference value (Fig. 3), the picture was exactly the same as the one mentioned above, i. e. a decreased ${ }^{14} \mathrm{CO}_{2}$ production $\left(p<0.02\right.$ or less) from either $\mathrm{D}-\left[6-{ }^{14} \mathrm{C}\right]$ glucose, $\mathrm{L}-$ $\left[1-{ }^{14} \mathrm{C}\right]$ leucine, L-[U- $\left.-{ }^{14} \mathrm{C}\right]$ leucine or 2 -keto[ $\left.1-{ }^{14} \mathrm{C}\right]$ isocaproate but a normal oxidation of $\left[1-{ }^{14} \mathrm{C}\right]$ pyruvate and $\left[2-{ }^{14} \mathrm{C}\right]$ pyruvate in the islets of GK rats.

In addition, paired data collected from the same islet preparations and within the same experiments with either $\mathrm{L}-\left[1-{ }^{14} \mathrm{C}\right]$ leucine and $\mathrm{L}-\left[\mathrm{U}-{ }^{14} \mathrm{C}\right]$ leucine or

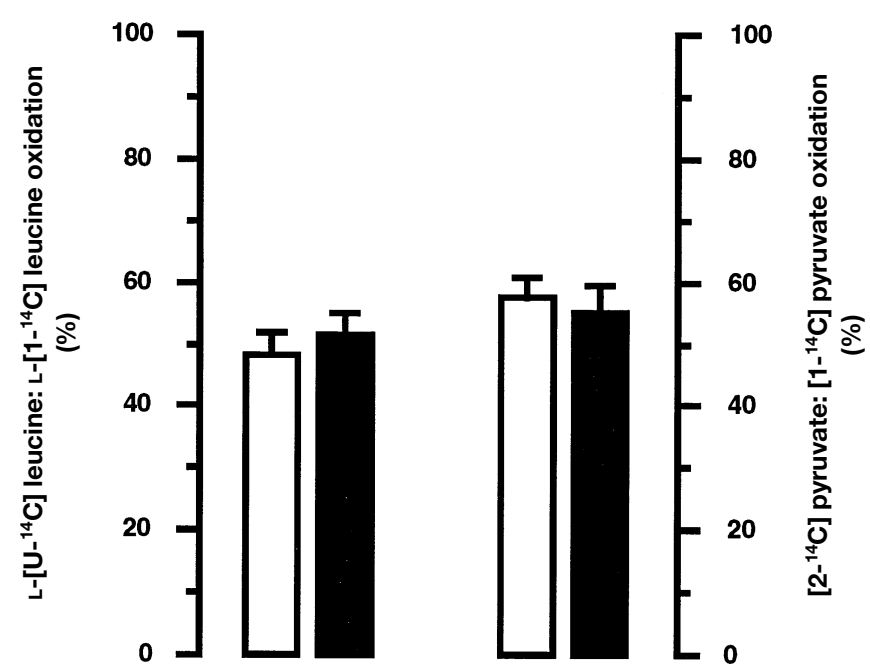

Fig. 4. Paired ratios of ${ }^{14} \mathrm{CO}_{2}$ generations from $\mathrm{L}-\left[\mathrm{U}-{ }^{14} \mathrm{C}\right] \mathrm{leu}-$ cine and $\mathrm{L}-\left[1-{ }^{14} \mathrm{C}\right]$ leucine, respectively (left) and from $\left[2-{ }^{14} \mathrm{C}\right]$ pyruvate and $\left[1-{ }^{14} \mathrm{C}\right]$ pyruvate, respectively (right) in islets from control Wistar (open bars) and diabetic GK (solid bars) rats. Each bar represents means \pm SEM for 31-46 batches of islets obtained from four or more distinct islet preparations

$\left[1-{ }^{14} \mathrm{C}\right]$ pyruvate and $\left[2-{ }^{14} \mathrm{C}\right]$ pyruvate, were used to calculate the oxidation of acetyl-CoA residues generated from leucine and pyruvate, respectively. In the control islets $48 \pm 4 \%(n=46)$ of the decarboxylated leucine was oxidized in the Krebs cycle, judged by the ratio between the amounts of ${ }^{14} \mathrm{CO}_{2}$ produced from $\mathrm{L}-\left[\mathrm{U}-{ }^{14} \mathrm{C}\right]$ leucine and $\mathrm{L}-\left[1-{ }^{14} \mathrm{C}\right]$ leucine, respectively (Fig. 4). In the islets from GK rats, the fraction of decarboxylated leucine being oxidized was similar, with a value of $51 \pm 4 \%(n=44)$. The proportion of pyruvate being oxidized into the Krebs cycle was also identical in the islets from control and diabetic animals averaging $58 \pm 3 \%(n=39)$ and $55 \pm 4 \%$ $(n=31)$, respectively, estimated by the ratio between the yields of the ${ }^{14} \mathrm{CO}_{2}$ from $\left[2-{ }^{14} \mathrm{C}\right]$ pyruvate and [1${ }^{14}$ C]pyruvate.

In these experiments the generation of ${ }^{14} \mathrm{C}$-labelled acidic metabolites in islets exposed to $\mathrm{L}$-[1${ }^{14} \mathrm{C}$ leucine and that of ${ }^{14} \mathrm{C}$-labelled amino acids in islets exposed to ${ }^{14} \mathrm{C}$-labelled pyruvate were also measured, such determinations providing information on the operation of transamination reactions in intact islets. The generation of ${ }^{14} \mathrm{C}$-labelled acidic metabolites (i.e. 2-keto[1-14 C]isocaproate) by islets exposed to $\mathrm{L}-\left[1-{ }^{14} \mathrm{C}\right]$ leucine was higher $(p<0.05)$ in diabetic $\left(10.4 \pm 1.8 \mathrm{pmol} \cdot 120 \mathrm{~min}^{-1} \cdot\right.$ islet $\left.^{-1}\right)$ than in control rats $\left(6.0 \pm 0.9 \mathrm{pmol} \cdot 120 \mathrm{~min}^{-1} \cdot\right.$ islet $\left.^{-1}\right)$. The sum of the rates of ${ }^{14} \mathrm{CO}_{2}$ and ${ }^{14} \mathrm{C}$-labelled acidic metabolite productions, both expressed as leucine equivalent with the same specific radioactivity as that of exogenous $\mathrm{L}-\left[1-{ }^{14} \mathrm{C}\right]$ leucine, was, however, similar $(p>0.5)$ in the two experimental groups, such a calculated value averaging in GK rat islets $88 \pm 11 \%(n=33)$ of the value found in control islets $(100 \pm 8 \%, n=35)$. 
These results reinforce the enzymatic data suggesting that there is no alteration of the leucine transamination process in the islets of diabetic animals. In addition, the generation of radioactive amino acids, presumably mainly radioactive alanine, by islets exposed to ${ }^{14} \mathrm{C}$-labelled pyruvate was similar in control and GK rat islets averaging, when expressed as pyruvate residues, $10.0 \pm 0.6(n=75)$ and $11.3 \pm 1.3(n=61)$ $\mathrm{pmol} \cdot 120 \mathrm{~min}^{-1} \cdot$ islet $^{-1}$, respectively. This suggests that the transamination reaction catalysed by alanine aminotransferase also failed to be affected in the islets of GK rats.

Lastly, the oxidation rate of $\mathrm{L}_{-}\left[\mathrm{U}-{ }^{14} \mathrm{C}\right]$ glutamine $(10.0 \mathrm{mmol} / \mathrm{l})$ was enhanced $(p<0.001)$ by the presence of $10.0 \mathrm{mmol} / \mathrm{l} \mathrm{L}$-leucine in the incubation medium both in control and diabetic groups (data not shown). The extent of such an enhancing effect was similar in islets from $\mathrm{GK}$ and control rats (factor of multiplication of $1.6 \pm 0.1, n=15$ and $1.7 \pm 0.1, n=18$, respectively). By contrast, the addition of L-glutamine $(10.0 \mathrm{mmol} / \mathrm{l})$ upon $\mathrm{L}-\left[1-{ }^{14} \mathrm{C}\right]$ leucine oxidation rate had no effect either in control or in GK rat islets and the presence of L-glutamine exerted an inhibitory effect on $\mathrm{L}_{-}\left[\mathrm{U}-{ }^{14} \mathrm{C}\right]$ leucine oxidation both in control and GK rat islets, the inhibition being almost identical in extent in the two experimental groups. Thus, in the presence of L-glutamine the ${ }^{14} \mathrm{CO}_{2}$ output from L-[U$\left.{ }^{14} \mathrm{C}\right]$ leucine averaged in control and $\mathrm{GK}$ rat islets, $68 \pm 9 \%(n=10)$ and $57 \pm 11 \%(n=9)$, respectively, of the corresponding mean value found in the same experiments in the absence of L-glutamine $(100 \pm 22 \%$ and $100 \pm 36 \%$, respectively; $n=4$ in both).

Insulin secretion. In the last series of experiments, we examined the secretory response of pancreatic islets to the major secretagogues used in the above metabolic studies, namely D-glucose, L-leucine, 2-ketoisocaproate (KIC), L-glutamine, as well as to the nonmetabolizable analogue of L-leucine, 2-amino-bicyclo[2,2,1]heptane-2-carboxylic acid (BCH).

The basal release of insulin, measured in the presence of a non-stimulatory D-glucose concentration $(2.8 \mathrm{mmol} / \mathrm{l})$ and expressed on the basis of the paired DNA content of islets to take into account the decreased beta-cell mass in the islets of GK rats, was similar in the two experimental groups, averaging $212 \pm 25$ and $188 \pm 46 \mathrm{pg} \cdot 90 \mathrm{~min}^{-1} \cdot \mathrm{ng}$ islet $\mathrm{DNA}^{-1}$, respectively ( $n=14$ in both).

In fair agreement with our previous report [3], the islets isolated from GK rats, compared with islets removed from Wistar rats, showed a large impairment in their insulin secretory response to D-glucose as well as to L-leucine. Thus, the insulin output averaged, in control and diabetic rat islets, $1308 \pm 86$ and $396 \pm 33 \mathrm{pg} \cdot 90 \mathrm{~min}^{-1} \cdot \mathrm{ng}$ islet $\mathrm{DNA}^{-1}$ in the presence of $16.7 \mathrm{mmol} / \mathrm{l}$ D-glucose, and $439 \pm 41$ and $183 \pm 44 \mathrm{pg} \cdot 90 \mathrm{~min}^{-1} \cdot \mathrm{ng}$ islet $\mathrm{DNA}^{-1}$ in the presence of $10.0 \mathrm{mmol} / \mathrm{l}$ L-leucine, both respectively such differences between the two experimental groups being highly $(p<0.001)$ significant.

When islets are exposed to $10.0 \mathrm{mmol} / \mathrm{KIC}$, the output of insulin was also much lower $(p<0.01)$ in GK $\left(292 \pm 69 \mathrm{pg} \cdot 90 \mathrm{~min}^{-1} \cdot \mathrm{ng}\right.$ islet $\left.\mathrm{DNA}^{-1}\right)$ than control group $\left(498 \pm 22 \mathrm{pg} \cdot 90 \mathrm{~min}^{-1} \cdot \mathrm{ng}\right.$ islet $\mathrm{DNA}^{-1}$ ). A lack of insulin response to the immediate deamination product of L-leucine constitute, therefore, another characteristic of islets in diabetic animals.

It should be stressed that such a deficient secretory response of beta cells to these three nutrient secretagogues coincided with a lower insulin content in the beta cells of diabetic than control rats. The ratio between islet insulin output and content was, however, lower in the three cases in GK than in control rats. For instance, under L-leucine stimulation, such a ratio averaged in islets from GK rats only $(p<0.025)$ $69 \pm 11 \%(n=14)$ of that recorded under the same experimental conditions in control rats $(100 \pm 6 \%$; $n=14)$.

By contrast, the insulin secretory response of islets to $10.0 \mathrm{mmol} / \mathrm{l} \mathrm{BCH}$ was not statistically significantly different in GK and control rats whether the results are expressed as the absolute value ( $313 \pm 73$ and $448 \pm 42 \mathrm{pg}$ insulin $\cdot 90 \mathrm{~min}^{-1} \cdot \mathrm{ng}$ islet $\mathrm{DNA}^{-1}$ in diabetic and control rat islets, respectively), relative to the basal release measured within the same type of rats and within the same experiment (paired data) in the presence of $2.8 \mathrm{mmol} / \mathrm{l} \mathrm{D}$-glucose $(191 \pm 20$ and $221 \pm 15 \%$ in diabetic and control rat islets, respectively) or as the percentage of the insulin content of islets from the same preparation $(9 \pm 2$ and $9 \pm 1 \%$ in diabetic and control rat islets, respectively).

Islets were also exposed to the combination of Lleucine with either $\mathrm{BCH}$ or L-glutamine $(10 \mathrm{mmol} / \mathrm{l}$ each). In both experimental groups, the association L-leucine plus $\mathrm{BCH}$ or L-leucine plus L-glutamine increased ( $p<0.005$ or less) the output of insulin, compared with the paired basal release. In both cases, the insulin output remained, however, lower $(p<0.001)$ in the islets from diabetic $(283 \pm 42$ and $281 \pm 31 \mathrm{pg} \cdot 90 \mathrm{~min}^{-1} \cdot \mathrm{ng}$ islet $\mathrm{DNA}^{-1}$ in the presence of the combination leucine- $\mathrm{BCH}$ and leucineglutamine, respectively) than in control rats $\left(635 \pm 50\right.$ and $959 \pm 77 \mathrm{pg} \cdot 90 \mathrm{~min}^{-1} \cdot \mathrm{ng}$ islet $\mathrm{DNA}^{-1}$ in the presence of the combination leucine$\mathrm{BCH}$ and leucine-glutamine, respectively). It is known that L-glutamine alone, unlike L-leucine alone, is not insulinotropic and that it enhances the insulinotropic effect of L-leucine [23, 43]. Our data obtained in control islets clearly illustrate this enhancing action of L-glutamine upon insulin release evoked by L-leucine (Fig. 5, left panel). They further indicate that the combination of $\mathrm{L}$-leucine and $\mathrm{BCH}$ exerts a more potent insulinotropic effect than L-leucine or $\mathrm{BCH}$ alone (Fig.5, left panel). In the islets from diabetic $\mathrm{GK}$ rats, the addition of $\mathrm{BCH}$ or $\mathrm{L}$-glu- 
A

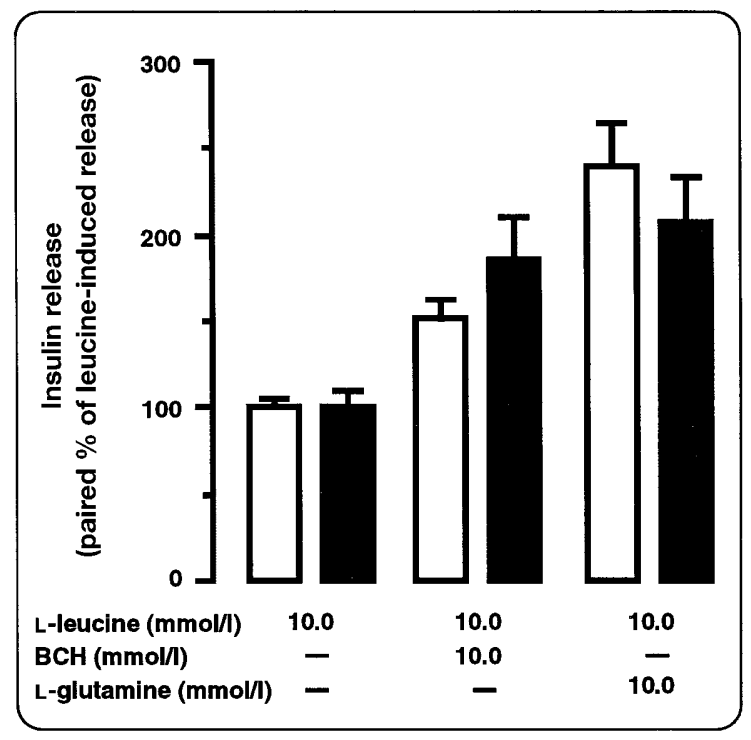

B

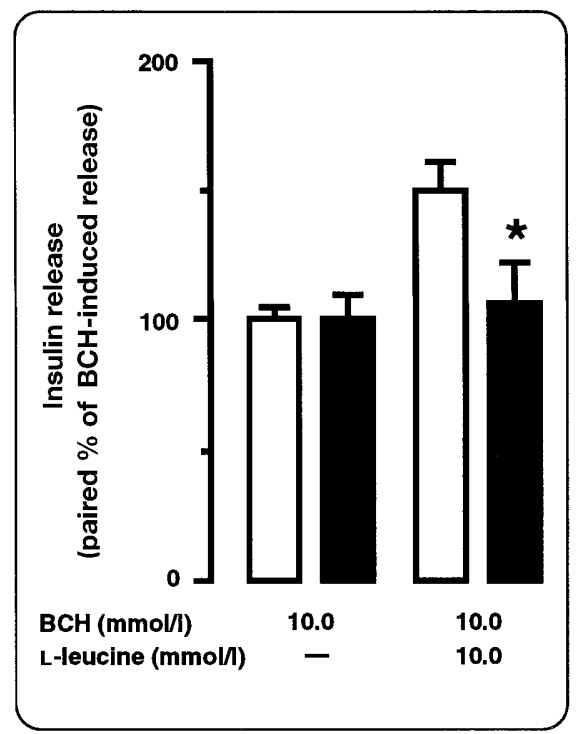

Fig.5 A, B. Insulin release by islets of control Wistar (open bars) and diabetic GK (solid bars) rats exposed to nutrient secretagogues. A The data are expressed as per cent of the mean value recorded, within the same experiment and in each type of animals, in the sole presence of L-leucine (paired data). B The data are expressed as per cent of the mean value recorded, within the same experiment and in each type of animals, in the sole presence of $\mathrm{BCH}$ (paired data). All data are means \pm SEM for 14 distinct determinations. Significance is given for a chance difference vs the control group: *, $p<0.05$

tamine enhanced ( $p<0.005$ or less, paired comparison of the data) the beta-cell secretory response induced by L-leucine to the same extent as in control islets (Fig. 5, left panel). On the contrary, addition of L-leucine, which 1.5-fold amplified $(p<0.001$, paired comparison of the data) $\mathrm{BCH}$-stimulated insulin output in controls, failed to elicit a statistically significant increase of the insulin output above the value found in the sole presence of $\mathrm{BCH}$ in the islets from GK rats (Fig. 5, right panel).

\section{Discussion}

These data are in fair agreement with our earlier observations showing a deficient insulin output in response to both glucose and leucine in the islets from GK rats [3]. So far, most of the studies on the endocrine function of pancreas in GK rats were focused on the cellular mechanisms behind the impaired insulin response to the hexose [3-7, 10, 11, 14-16, 44-47]. The current study was the first attempt to identify the factor(s) responsible for the deficient beta-cell response to the amino acid in this model of Type II diabetes. Our results show that the insulin output evoked by KIC, the first derivative of leucine catabo- lism, is also reduced in the islets of GK rats. At first glance, this secretory behaviour is not surprising since it can be argued that it is associated with a decreased insulin availability in the islets. The data shown herein indicate, in accordance with our previous reports $[3,48]$, that islets of GK rats originating from our colony show decreased beta-cell mass and low insulin content compared with control islets. The islet DNA content was decreased to a similar extent to that of the islet beta cells. This is consistent with our morphometric data which indicates that there is no major change in the relative contribution of beta cells to total endocrine cells in the GK rat islets. This last observation accords with results obtained with GK rats from three other colonies $[4,11,46]$. In addition, in GK rat islets the insulin content, when expressed relative to the DNA content, remains lower than in control islets which is in support of a degranulation in the beta cells of the diabetic animals [45, 49].

This study provides, however, evidence that, even if the decreased beta-cell mass and insulin store in GK rat islets could contribute to their poor insulin secretory capacity, the failure of leucine as well as KIC to stimulate the hormonal release is also due to an impaired stimulus-secretion coupling for these secretagogues. Firstly, the insulin secretion evoked by each of these secretagogues, when expressed as a percentage of the islet insulin content, remained lower in the islets from GK than control rats. Secondly, the islet beta cells of GK rats are able to respond properly to other secretagogues such as the artificial leucine analogue $\mathrm{BCH}$ which, under our experimental conditions, induced an insulin output of the same magnitude as L-leucine in control islets. It should be noted that these results of the insulinotropic effect of $\mathrm{BCH}$ in GK rat islets, although agreeing with our previous observations [13], are at variance with the data of another study [45] showing an impaired secretory re- 
sponse of the islets from GK rats to this secretagogue. We have no explanation for these differences, but these results were obtained in two distinct GK rat colonies. There is contradictory data on GK rats suggesting that differences in genetic or environmental conditions (e.g. colony, food, age, etc.) or both might be responsible for the differences so far reported and related to morphology $[4,11,46,48,50]$, insulin content of islets $[3,5-7,10,16,45]$ or intra-islet glucose metabolism $[3,5,6,10]$. Our observation of a disturbed KIC-induced insulin release in GK rat islets is in line with our earlier observations [12] but contradicts other data [44]. The authors of the report of that data showed with the patch-clamp technique that KIC, in contrast to glucose, closed the ATP-sensitive $\mathrm{K}^{+}$channels normally in islets isolated from GK rats and they asserted, from unpublished observations, that the enhancement of insulin secretion by this keto acid is almost identical between GK and control rat islets. Also conflicting, at first glance, with our data are the data of two reports $[6,51]$ showing a maintained insulin response to KIC in the islets of the diabetic animals. In the first of these two papers, it can, however, be observed when scrutinizing the results, which were obtained in the London GK rat colony, that the KIC-stimulated insulin release was approximately $30 \%$ lower in GK rat islets than in controls, even though the difference between the two experimental groups was not found statistically significant. In the second paper, the animals used were F1-hybrid rats obtained from crosses between female Wistar and male GK rats from the Stockholm colony. In addition the authors also mentioned in the discussion section of this paper that, in contrast to hybrid rats, islet insulin release induced by KIC was found decreased in Stockholm GK rats. Lastly, our data further shows that, in GK rat islets, whereas the enhancing action of either L-glutamine or $\mathrm{BCH}$ upon leucine-stimulated insulin release is preserved, $\mathrm{L}-\mathrm{leu}$ cine addition failed to amplify $\mathrm{BCH}$-stimulated insulin output as it is in controls.

Because the leucine-induced insulin release occurs partly as a consequence of the leucine metabolism within the beta cells [17-19], we made the assumption that the loss of insulin response to L-leucine in the islets from GK rats could be due to a reduced leucinemetabolism within their insular cells. Our measurements of $\mathrm{L}-\left[1-{ }^{14} \mathrm{C}\right]$ leucine uptake by intact islets suggest that there is no major defect in the transport of amino acid across the plasma membrane in the islet cells of diabetic GK rats. From the two independent sets of data mentioned below, it also seems clear that the secretory failure of the beta-cell response to Lleucine in the GK rat islets cannot be blamed on any anomaly in the first step of the intra-islet pathway of L-leucine metabolism, in which L-leucine is converted by a branched chain amino acid aminotransferase (transaminase) to the keto acid KIC. Firstly, leucine- glutamate transaminase activity, measured in crude islet homogenates, was found identical in the diabetic and control groups. Secondly, the total generation of both ${ }^{14} \mathrm{CO}_{2}$ and ${ }^{14} \mathrm{C}$-labelled acidic metabolites by intact islets exposed to $\mathrm{L}-\left[1-{ }^{14} \mathrm{C}\right]$ leucine was also similar in the two experimental groups. Instead, our results indicate that, in GK rat islets, the generation of ${ }^{14} \mathrm{CO}_{2}$ from either L- $\left[1-{ }^{14} \mathrm{C}\right]$ leucine, $\mathrm{L}-\left[\mathrm{U}-{ }^{14} \mathrm{C}\right]$ leucine or 2-keto[ $\left[1-{ }^{14} \mathrm{C}\right]$ isocaproate $\left(\left[1-{ }^{14} \mathrm{C}\right] \mathrm{KIC}\right)$, and $\mathrm{D}-[6-$ $\left.{ }^{14} \mathrm{C}\right]$ glucose as well, is statistically significantly lower than that recorded in respective controls. We found, however, a normal oxidation of $\left[1-{ }^{14} \mathrm{C}\right]$ pyruvate and $\left[2-{ }^{14} \mathrm{C}\right]$ pyruvate in the islets of $\mathrm{GK}$ rats and both the $\mathrm{L}-\left[\mathrm{U}-{ }^{14} \mathrm{C}\right]$ leucine oxidation : $\mathrm{L}-\left[1-{ }^{14} \mathrm{C}\right]$ leucine decarboxylation ratio and the ratio of the yields of the ${ }^{14} \mathrm{CO}_{2}$ from $\left[2-{ }^{14} \mathrm{C}\right]$ pyruvate and $\left[1-{ }^{14} \mathrm{C}\right]$ pyruvate were also found normal. Altogether, these data give information on three steps of L-leucine metabolism in the islets of GK rats.

Firstly, the metabolic data collected in islets exposed to either $\mathrm{L}-\left[1-{ }^{14} \mathrm{C}\right]$ leucine or $\left[1-{ }^{14} \mathrm{C}\right] \mathrm{KIC}$ point to a perturbation in the activity of the mitochondrial branched-chain ketoacid dehydrogenase (BCKDH) multi-enzyme complex, which catalyses KIC oxidative decarboxylation, in the islets of GK rats, even though no direct measurement of this enzymatic activity was made in the present study. The BCKDH enzyme complex is thought to be structurally and functionally closely related to the pyruvate dehydrogenase (PDH) multi-enzyme complex which catalyses oxidative decarboxylation of pyruvate [52]. Note a decreased activity of PDH, likely to be due to enhanced PDH kinase activity, has already been shown in GK rat islets [16]. Nevertheless, at first glance, our present data collected in islets of GK rats from our colony does not support such a defect since ${ }^{14} \mathrm{CO}_{2}$ production from $\left[1-{ }^{14} \mathrm{C}\right]$ pyruvate was found normal. The reason for this discrepancy is not clear. It is, however, of note that the generation of ${ }^{14} \mathrm{CO}_{2}$ from $\left[1-{ }^{14} \mathrm{C}\right]$ pyruvate probably does not inform on the true activity of PDH, since pyruvate seems to enter the Krebs cycle in islets by carboxylation to as great an extent or more than by decarboxylation in the reaction catalysed by pyruvate carboxylase and $\mathrm{PDH}$, respectively [53]. Thus, $\mathrm{CO}_{2}$ is released from carbon 1 of pyruvate when this latter is converted to acetyl-CoA in the reaction of decarboxylation but is also formed from carbon 1 of pyruvate when pyruvate is carboxylated and metabolized in the Krebs cycle. The normal rate of labelled pyruvate oxidation in GK rat islets could also seem, at first glance, inconsistent with the suppressed ${ }^{14} \mathrm{CO}_{2}$ production from $\mathrm{D}$-[6${ }^{14} \mathrm{C}$ ]glucose observed in the same islets. Alternatively, defect(s) upstream to pyruvate carboxylation or decarboxylation [3-6, 10-15] could result in an inadequate generation of pyruvate from $\mathrm{D}$-glucose accounting for the decrease ${ }^{14} \mathrm{CO}_{2}$ production from D$\left[6-{ }^{14} \mathrm{C}\right]$ glucose irrespective of other potential pertur- 
bations in pyruvate metabolism. Such a view is supported by our previous reports of a reduced aerobic glycolysis in GK rat islets [3,10], as the result of a decreased metabolic flux through the glycerol phosphate shuttle due to altered FAD-dependent glycerophosphate dehydrogenase insular activity [12-14].

Secondly, the paired data recorded with L-[1$\left.{ }^{14} \mathrm{C}\right]$ leucine and $\mathrm{L}-\left[\mathrm{U}-{ }^{14} \mathrm{C}\right]$ leucine indicate that in the islets from Goto-Kakizaki (GK) rats the acetyl-CoA residues generated through leucine decarboxylation undergo oxidation in the Krebs cycle to the same extent as in control islets. These results and that the percentage of ${ }^{14} \mathrm{CO}_{2}$ produced from $\left[2-{ }^{14} \mathrm{C}\right]$ pyruvate relative to that generated from $\left[1-{ }^{14} \mathrm{C}\right]$ pyruvate was found similar in the diabetic and control islets, corroborate our previous proposal based on results from incubations of islets with both $\left[6-{ }^{14} \mathrm{C}\right]-$ and $\left[3,4-{ }^{14} \mathrm{C}\right]$ glucose, that the Krebs cycle itself is not perturbed in GK rat beta cells [10].

Thirdly, the unimpaired $\mathrm{L}-\left[\mathrm{U}_{-}{ }^{14} \mathrm{C}\right]$ leucine oxidation : $\mathrm{L}-\left[1-{ }^{14} \mathrm{C}\right]$ leucine decarboxylation ratio in the islets of GK rats also makes the existence of defects in leucine catabolism events located at sites proximal to Krebs cycle but distal to KIC oxidative decarboxylation (i.e. in the generation of acetyl-CoA from isovaleryl-CoA) unlikely. This is supported by data showing normal activity of the methylcrotonyl-CoA carboxylase, which catalyses the carboxylation of 3methylcrotonyl-CoA to 3-methylglutaconyl-CoA, in GK rat islets [15].

Finally, since it is generally agreed that part of the insulinotropic action of leucine occurs through stimulation of glutamate metabolism due to the allosteric activation of glutamate dehydrogenase by the amino acid [20-25], a deficiency in this metabolic pathway could possibly also explain the lack of beta-cell secretory responsiveness to leucine in islets of GK rats. The experiments presented here strongly argue against such an hypothesis. Both the glutamate dehydrogenase activity and the oxidation of the L-glutamate precursor L-glutamine were found normal in islets from GK rats suggesting that this metabolic pathway is operational. Moreover, L-glutamine, which by itself is ineffective, potentiated the insulin output recorded in islets exposed to L-leucine to the same extent as in control islets. In addition, in GK rat islets, the insulin secretory response to the L-leucine nonmetabolizable analogue $\mathrm{BCH}$, as well as the enhancing effect of $\mathrm{BCH}$ on the leucine-mediated insulin output, were preserved. These last findings suggest that in the islets of diabetic animals the sensitivity of glutamate dehydrogenase to its allosteric activators L-leucine and $\mathrm{BCH}$ is not changed and the amount of endogenous glutamate is not a rate-limiting factor for the leucine insulinotropic effect through the glutamate route.

This study has shown that L-leucine failed to stimulate insulin release and amplify the beta-cell secre- tory response to the leucine non-metabolizable analogue $\mathrm{BCH}$ in islets from GK rats. This deterioration in secretory behaviour was paralleled by an inadequate production of ${ }^{14} \mathrm{CO}_{2}$ by the islets exposed to either $\mathrm{L}-\left[\mathrm{U}-{ }^{14} \mathrm{C}\right]$ leucine, $\mathrm{L}-\left[1-{ }^{14} \mathrm{C}\right]$ leucine or $\left[1-{ }^{14} \mathrm{C}\right] \mathrm{KIC}$. In contrast, the insulin secretory response of $\mathrm{GK}$ rat islets to $\mathrm{BCH}$ was preserved as well as the enhancing effect of $\mathrm{BCH}$ on the leucine-mediated insulin output. The potentiating action of L-glutamine on insulin release evoked by L-leucine was also intact. This coincided with normal activity of glutamate dehydrogenase in islet homogenates and normal oxidation of $\mathrm{L}-\left[\mathrm{U}-{ }^{14} \mathrm{C}\right]$ glutamine in intact islets. In the islet cells of GK rats, leucine transport and transamination processes were also both unchanged; and the ratio between $\mathrm{L}-\left[\mathrm{U}-{ }^{14} \mathrm{C}\right]$ leucine oxidation and $\mathrm{L}-\left[1-{ }^{14} \mathrm{C}\right]$ leucine decarboxylation was similar to that measured in controls.

As a whole, these findings strongly suggest that in beta cells of diabetic GK rats, at least those originating from the Paris colony, the defective leucine-stimulated insulin secretion cannot be attributed to a major change in leucine-stimulated glutamate metabolism. It is more probably linked to the impairment of the catabolism of leucine itself. Since leucine uptake, leucine deamination and the oxidation of acetyl-CoA residues generated from leucine by the islet cells remained intact, the defect could be at the level of the generation of acetyl-CoA from KIC. Moreover, as the $\mathrm{CO}_{2}$ production from $\mathrm{L}-\left[{ }^{14} \mathrm{C}\right]$ leucine is decreased in GK rat islets, we propose that the impaired insulin secretory response to L-leucine recorded in the islets from the diabetic rats is principally attributable to the defective mitochondrial oxidative decarboxylation of KIC operated by the branched-chain 2-ketoacid dehydrogenase (BCKDH) enzymatic complex. Note a negative effect of a high glucose concentration on the activity of this latter enzymatic complex in 24-h cultured islets has been reported [54]. This effect was attributed to suppression of the synthesis of the enzyme because of the down regulation by glucose of the gene encoding the E1 $\alpha$ catalytic subunit ( $\alpha$ subunit of BCK carboxylase) of the E1 component of the BCKDH.

Acknowledgements. We are grateful to Mrs D. Bailbé for her expert assistance in the GK rat breeding. We also thank Dr V.Leclercq-Meyer (Brussels Free University, Brussels, Belgium) for kindly supplying insulin antibody.

Parts of this work were presented at the 31 th Annual Meeting of the European Association for the Study of Diabetes, Stockholm, Sweden, 12-16 September 1995 and have appeared in abstract form (Giroix M-H, Portha B. Diabetologia 38 [suppl 1]: A 103, 1995). 


\section{References}

1. Kimura K, Toyota T, Kakizaki M, Kudo M, Takebe K, Goto Y (1982) Impaired insulin secretion in the spontaneous diabetic rats. Tohoku J Exp Med 137: 453-459

2. Portha B, Serradas P, Bailbé D, Suzuki K-I, Goto Y, Giroix M-H (1991) $\beta$-Cell insensitivity to glucose in the GK rat, a spontaneous nonobese model for type II diabetes. Diabetes 40: 486-491

3. Giroix M-H, Vesco L, Portha B (1993) Functional and metabolic perturbations in isolated pancreatic islets from the GK rat, a genetic model of noninsulin-dependent diabetes. Endocrinology 132: 815-822

4. Ohneda M, Johnson JH, Inman LR et al. (1993) GLUT 2 expression and function in $\beta$-cells of GK rats with NIDDM. Dissociation between reductions in glucose transport and glucose-stimulated insulin secretion. Diabetes 42: 10651072

5. Östenson C-G, Khan A, Abdel-Halim SM et al. (1993) Abnormal insulin secretion and glucose metabolism in pancreatic islets from the spontaneously diabetic GK rat. Diabetologia 36: 3-8

6. Hughes SJ, Suzuki K, Goto Y (1994) The role of islet secretory function in the development of diabetes in the GK Wistar rat. Diabetologia 37: 863-870

7. Katayama N, Hughes SJ, Persaud SJ, Jones PM, Howell SL (1995) Insulin secretion from islets of GK rats is not impaired after energy generating steps. Mol Cell Endocrinol 111: $125-128$

8. Goto Y, Kakizaki M, Masaki N (1975) Spontaneous diabetes produced by selective breeding of normal Wistar rats. Proc Jpn Acad 51: 80-85

9. Goto Y, Kakizaki M (1981) The spontaneous-diabetes rat: a model of noninsulin dependent diabetes mellitus. Proc Jpn Acad 57: 381-384

10. Giroix M-H, Sener A, Portha B, Malaisse WJ (1993) Preferential alteration of oxidative relative to total glycolysis in pancreatic islets of two rat models of inherited or acquired type 2 (non-insulin-dependent) diabetes mellitus. Diabetologia 36: 305-309

11. Östenson C-G, Abdel-Halim SM, Rasschaert J et al. (1993) Deficient activity of FAD-linked glycerophosphate dehydrogenase in islets of GK rats. Diabetologia 36: 722-726

12. Giroix M-H, Sener A, Portha B, Malaisse WJ (1994) Enzymatic and secretory activities in pancreatic islets of non-insulin-dependent diabetic rats after short-term infusion of succinic acid monomethylester. Biochem Med Metab Biol 53: $115-121$

13. Rasschaert J, Giroix M-H, Conget I et al. (1994) Pancreatic islet response to dicarboxylic acid esters in rats with type 2 diabetes: enzymatic, metabolic and secretory aspects. J Mol Endocrinol 13: 209-217

14. Fabregat ME, Novials A, Giroix M-H, Sener A, Gomis R, Malaisse WJ (1996) Pancreatic islet mitochondrial glycerophosphate dehydrogenase deficiency in two animal models of non-insulin-dependent diabetes mellitus. Biochem Biophys Res Commun 220: 1020-1023

15. MacDonald MJ, Efendic S, Östenson C-G (1996) Normalization by insulin treatment of low mitochondrial glycerol phosphate dehydrogenase and pyruvate carboxylase in pancreatic islets of the GK rat. Diabetes 45: 886-890

16. Zou Y-P, Östenson C-G, Ling Z-C, Grill V (1995) Deficiency of pyruvate dehydrogenase activity in pancreatic islets of diabetic GK rats. Endocrinology 136: 3546-3551

17. Malaisse WJ, Hutton JC, Carpinelli AR, Herchuelz A, Sener A (1980) The stimulus-secretion coupling of amino acid-induced insulin release. Metabolism and cationic effects of leucine. Diabetes 29: 431-437

18. Lenzen S, Formanek H, Panten U (1982) Signal function of metabolism of neutral amino acids and 2-keto acids for initiation of insulin secretion. J Biol Chem 257: 6631-6633

19. Lenzen S, Schmidt W, Panten U (1985) Transamination of neutral amino acids and 2-keto acids in pancreatic B-cell mitochondria. J Biol Chem 260: 12629-12634

20. Lenzen S, Schmidt W, Rustenbeck I, Panten U (1986) 2Ketoglutarate generation in pancreatic B-cell mitochondria regulates insulin secretory action of amino acids and 2-keto acids. Biosci Rep 6: 163-169

21. Gylfe E (1976) Comparison of the effects of leucines, nonmetabolizable leucine analogues and other insulin secretagogues on the activity of glutamate dehydrogenase. Acta Diabetol 13: 20-24

22. Panten U, Holze S, Lenzen S (1980) Changes of function and metabolism of the pancreatic B-cell caused by amino acids and related compounds. Horm Metab Res [Suppl 10]: 27-30

23. Sener A, Malaisse WJ (1980) L-leucine and a nonmetabolized analogue activate pancreatic islet glutamate dehydrogenase. Nature 288: 187-189

24. Sener A, Malaisse-Lagae F, Malaisse WJ (1981) Stimulation of islet metabolism and insulin release by a nonmetabolizable amino acid. Proc Natl Acad Sci U S A 78: 5460-5464

25. Panten U, Zielmann S, Langer J, Zünkler B-J, Lenzen S (1984) Regulation of insulin secretion by energy metabolism in pancreatic B-cell mitochondria. Studies with a nonmetabolizable leucine analogue. Biochem J 219: 189-196

26. Hellman B, Sehlin J, Täljedal I-B (1971) Uptake of alanine, arginine, and leucine by mammalian pancreatic $\beta$-cells. Endocrinology 89: 1432-1439

27. Prentki M, Renold AE (1983) Neutral amino acid transport in isolated rat pancreatic islets. J Biol Chem 258: 14239-14244

28. Gylfe E (1988) Nutrient secretagogues induce bimodal early changes in cytoplasmic calcium of insulin-releasing ob/ ob mouse $\beta$-cells. J Biol Chem 263: 13750-13754

29. Henquin J-C, Meissner HP (1981) Effects of amino acids on membrane potential and ${ }^{86} \mathrm{Rb}^{+}$fluxes in pancreatic $\beta$ cells. Am J Physiol 240: E245-E252

30. Ashcroft FM, Ashcroft SJH, Harrison DE (1987) Effects of 2-ketoisocaproate on insulin release and single potassium channel activity in dispersed rat pancreatic $\beta$-cells. J Physiol 385: 517-529

31. Lacy PE, Kostianovsky M (1967) Method for the isolation of intact islets of Langerhans from the rat pancreas. Diabetes 16: 35-39

32. Giroix M-H, Sener A, Malaisse WJ (1986) Artefactual and true uptake of labelled sucrose by rat pancreatic islet cells. Comp Biochem Physiol 85A: 289-296

33. Malaisse-Lagae F, Malaisse WJ (1984) Insulin release by pancreatic islets. In: Larner J, Pohl SL (eds) Methods in Diabetes Research. Vol 1. part B. John Wiley \& Sons, New York, pp 147-152

34. Perales M-A, Sener A, Malaisse WJ (1992) Radioisotopic assay of aspartate and alanine aminotransferase. Clin Biochem 25: 105-107

35. Sener A, Malaisse WJ (1990) A sensitive radioisotopic method for the measurement of $\mathrm{NAD}(\mathrm{P}) \mathrm{H}$ : its application to the assay of metabolites and enzymatic activities. Anal Biochem 186: 236-242

36. Carpinelli AR, Sener A, Herchuelz A, Malaisse WJ (1980) Stimulus-secretion coupling of glucose-induced insulin re- 
lease. Effect of intracellular acidification upon calcium efflux from islet cells. Metabolism 29: 540-545

37. Avrameas S, Ternynck T (1971) Peroxidase labelled antibody and Fab conjugates with enhanced intracellular penetration. Immunochemistry 8: 1175-1179

38. Michel C, Chariot J, Souchard M, Rozé C (1982) Modifications of the endocrine pancreas in rats after ethionine destruction of acini. Cell Mol Biol 28: 138-148

39. Bergmeyer HU, Bernt E (1974) D-glucose determination with glucose oxidase and peroxidase. In: Bergmeyer HU (ed) Methods of Enzymatic Analysis. Academic Press, New York, pp 1205-1215

40. Freychet P, Roth J, Neville DM (1971) Monoiodo-insulin: demonstration of biological activity and binding to fat cells and liver membranes. Biochem Biophys Res Commun 43: 400-408

41. Labarca C, Paigen K (1980) A simple, rapid, and sensitive DNA assay procedure. Anal Biochem 102: 344-352

42. Hopcroft DW, Mason DR, Scott RS (1985) Standardization of insulin secretion from pancreatic islets: validation of a DNA assay. Horm Metab Res 17: 559-561

43. Malaisse-Lagae F, Sener A, Garcia-Morales P, Valverde I, Malaisse WJ (1982) The stimulus-secretion coupling of amino acid-induced insulin release. Influence of a nonmetabolized analog of leucine on the metabolism of glutamine in pancreatic islets. J Biol Chem 257: 3754-3758

44. Tsuura Y, Ishida H, Okamoto Yet al. (1993) Glucose sensitivity of ATP-sensitive $\mathrm{K}^{+}$channels is impaired in $\beta$-cells of the GK rat. A new genetic model of NIDDM. Diabetes 42: 1446-1453

45. Sener A, Malaisse-Lagae F, Östenson C-G, Malaisse WJ (1993) Metabolism of endogenous nutrients in islets of Goto-Kakizaki (GK) rats. Biochem J 296: 329-334

46. Kato S, Ishida H, Tsuura Y et al. (1996) Alterations in basal and glucose-stimulated voltage-dependent $\mathrm{Ca}^{2+}$ channel activities in pancreatic $\beta$ cells of non-insulin-dependent diabetes mellitus GK rats. J Clin Invest 97: 2417-2425

47. Ling Z-C, Efendic S, Wibom R et al. (1998) Glucose metabolism in Goto-Kakizaki rat islets. Endocrinology 139: 2670-2674

48. Serradas P, Giroix M-H, Saulnier C et al. (1995) Mitochondrial deoxyribonucleic acid content is specifically decreased in adult, but not fetal, pancreatic islets of the Goto-Kakizaki rat, a genetic model of noninsulino-dependent diabetes. Endocrinology 136: 5623-5631

49. Suzuki K-I, Goto Y, Toyota T (1992) Spontaneously diabetic GK (Goto-Kakizaki) rats. In: Shafrir E (ed) Lessons from Animal Diabetes IV, Vol 4. Smith-Gordon, London, pp 107-116

50. Guenifi A, Abdel-Halim SM, Höög A, Falkmer S, Östenson C-G (1995) Preserved $\beta$-cell density in the endocrine pancreas of young, spontaneously diabetic Goto-Kakizaki (GK) rats. Pancreas 10: 148-153

51. Guenifi A, Abdel-Halim SM, Efendic S, Östenson C-G (1998) Preserved initiatory and potentiatory effect of $\alpha$-ketoisocaproate on insulin release in islets of glucose intolerant rats. Diabetologia 41: 1368-1373

52. Randle PJ (1985) $\alpha$-ketoacid dehydrogenase complexes and respiratory fuel utilization in diabetes. Diabetologia 28: 479-484

53. MacDonald MJ (1993) Estimates of glycolysis, pyruvate (de)carboxylation, pentose-phosphate pathway and methyl succinate metabolism in incapacitated pancreatic islets. Arch Biochem Biophys 305: 205-214

54. MacDonald MJ, McKenzie DI, Kaysen JH et al. (1991) Glucose regulates leucine-induced insulin release and the expression of the branched chain ketoacid dehydrogenase E1 $\alpha$ subunit gene in pancreatic islets. J Biol Chem 266: 1335-1340 